RESEARCH REPORT

\title{
Is patriarchy the source of men's higher mortality?
}

\author{
D Stanistreet, C Bambra, A Scott-Samuel
}

J Epidemiol Community Health 2005;59:873-876. doi: 10.1136/jech.2004.030387

See end of article for authors' affiliations

......................

Correspondence to: Dr D Stanistreet, Division of Public Health, University of Liverpool, Whelan Building, The Quadrangle, Liverpool L69 3GB, UK: debbi@liv.ac.uk

Accepted for publication 11 May 2005
Objective: To examine the relation between levels of patriarchy and male health by comparing female homicide rates with male mortality within countries.

Hypothesis: High levels of patriarchy in a society are associated with increased mortality among men.

Design: Cross sectional ecological study design.

Setting: 51 countries from four continents were represented in the data-America, Europe, Australasia, and Asia. No data were available for Africa.

Results: A multivariate stepwise linear regression model was used. Main outcome measure was age standardised male mortality rates for 51 countries for the year 1995. Age standardised female homicide rates and GDP per capita ranking were the explanatory variables in the model. Results were also adjusted for the effects of general rates of homicide. Age standardised female homicide rates and ranking of GDP were strongly correlated with age standardised male mortality rates (Pearson's $r=0.699$ and Spearman's 0.744 respectively) and both correlations achieved significance $(p<0.005)$. Both factors were subsequently included in the stepwise regression model. Female homicide rates explained $48.8 \%$ of the variance in male mortality, and GDP a further $13.6 \%$ showing that the higher the rate of female homicide, and hence the greater the indicator of patriarchy, the higher is the rate of mortality among men.

Conclusion: These data suggest that oppression and exploitation harm the oppressors as well as those they oppress, and that men's higher mortality is a preventable social condition, which could be tackled through global social policy measures.
$\mathrm{P}$ atriarchy, which has been described as "a relationship of dominance and subordinance.... sturdier than any form of segregation, and more rigorous than class stratification, more uniform, certainly more enduring"1 and more simply as "the systematic domination of women by men and domination of men by other men", 2 is a key analytical concept in feminist social research. The interaction between patriarchy and women's health has been well reported..$^{3-6}$ However, the relation between patriarchy (although this term is seldom used explicitly) and male health has only recently begun to receive the same level of attention as part of an upsurge of interest in masculinity, gendered behaviour, and health. $^{7-12}$ In developed countries, men have a higher mortality rate than women at all ages ${ }^{13}{ }^{14}$ and on average they die nearly seven years earlier than women. ${ }^{15}$ Male mortality rates are higher across a number of different causes of mortality, such as coronary heart disease, lung cancer, suicide, liver cirrhosis, and sexually transmitted diseases. ${ }^{16}$ Increasingly, these differences are being attributed to variation in the behaviour of men and women. ${ }^{79}$ This in turn has led to the suggestion that patriarchy itself, through the sex roles and patterns of behaviour to which it gives rise, may be bad for men's health and lead to their higher mortality. ${ }^{15-17}$

Existing studies on patriarchy and male health have tended to have a specific country focus (usually the USA), ${ }^{15} 16^{18}$ and there has been no attempt at any cross national exploration of the relation between patriarchy and male mortality rates.

In the broader comparative literature certain countries are considered relatively less (for example, the Scandinavian countries) or more (for example, the UK and the USA) structured by sex than others. ${ }^{19-24}$ The relative level of patriarchy could thus be compared between countries using exposure measures, such as female participation in gainful employment, the proportion of women in decision making positions, or the sex division of household labour, ${ }^{25}$ or outcome measures, such as violence against women or the female homicide rate. ${ }^{26}$ Evidence suggests overwhelmingly that the perpetrators of sexual and domestic violence are men and the victims are women (and also children). ${ }^{26}{ }^{27}$ The high proportion of female homicides carried out by men makes this a valid indicator of patriarchy, at both individual and institutional levels, and data are available for a wide range of countries. Therefore we have studied cross national variation in the relation between levels of patriarchy and male health by comparing female homicide rates with male mortality within countries. Specifically we were interested in testing the hypothesis that high levels of patriarchy in a society are associated with increased mortality among men.

\section{METHODS}

Data on age standardised all cause male mortality rates and age standardised female homicide rates were obtained from the 1996 World Health Statistics Annual ${ }^{28}$ for 51 countries throughout the world (see appendix) for the year 1995 (or where this was not available, for 1994). The annual provides a detailed description of the validity and reliability of these data stating that publication is limited to those countries that report cause of death information in an appropriate format and in which death registration coverage can be estimated as reasonably good.

Countries from four continents were represented in the data-America (North and South), Europe, Australasia, and Asia. No data were available for African countries. Gross domestic product (GDP) per capita ranking for 1994 (countries ranked as high, medium, or low GDP per capita) was obtained from the Human Development Report $1997^{29}$ to adjust for the independent effect of the level of socioeconomic development between countries. The countries offered a wide range in terms of economic development, GDP per capita, ranging from 1126 dollars (Tajikistan) to 29010 dollars (USA). Age standardised male homicide rates 
Table 1 Model summary showing proportion of variance in the outcome variable explained by the predictors after adjusting for covariants in the model

\begin{tabular}{llll}
\hline Model & $r$ & $r^{2}$ & SE of the estimate \\
\hline $1^{*}$ & 0.699 & 0.488 & 195.84754 \\
$2 \dagger$ & 0.790 & 0.624 & 169.63524 \\
$3 \ddagger$ & 0.812 & 0.659 & 163.33279 \\
\hline
\end{tabular}

*Predictors: constant, female homicide (ln). †Predictors: constant, female homicide (ln), ranking based on GDP. ¥Predictors: constant, female homicide (ln), ranking based on GDP, male homicide (ln).

were also included in the model to adjust for the effects of general rates of homicide.

Homicide data were not normally distributed and were therefore logged. Age standardised female homicide rates and GDP per capita ranking were then correlated with age standardised male mortality rates. A multivariate stepwise linear regression model was used to distinguish the independent effect of female homicide on male mortality.

\section{RESULTS}

In all countries female life expectancy exceeded that for males. The distribution of two of the variables differed significantly from normal (Kolmogorov Smirnov statistic for normality, age standardised female homicide rate, $\mathrm{p}=0.007$; age standardised male homicide rate, $p=0.001$ ). Therefore these variables were transformed using the natural log. Each variable was then correlated with age standardised male mortality rates.

Age standardised female homicide rates and age standardised male homicide rates were found to be strongly correlated with age standardised male mortality rates (Pearson's $r=0.699$ and 0.625 respectively) and both correlations were highly significant $(p \leqslant 0.0005)$. GDP ranking was also strongly correlated with age standardised male mortality rates (Spearman's $r=0.744, \mathrm{p} \leqslant 0.0005$ ). All factors were then included in a stepwise regression model to assess the effect of each factor on the outcome variable (age standardised male mortality rates). The model is shown in tables 1 and 2. The regression equation for the model is:

male mortality rate $=503.281+0.955 \times \ln ($ female homicide rate $)+0.508 \times($ GDP ranking $)-0.489 \times \ln ($ male homicide rate)

Of the three factors in the model, female homicide rates had the greater influence. Female homicide rates alone, explain $48.8 \%$ of the variance in male mortality. When GDP is added to the model, a further $13.6 \%$ of the variance is explained and when male homicide is added a further $3.5 \%$ is explained (table 1). This shows that the higher the rate of female homicide, and hence the greater the level of patriarchy, the higher is the rate of mortality among men.

\section{DISCUSSION}

We have shown a substantial and significant association between nations' levels of patriarchy and men's higher

\section{What is already known}

Male mortality rates are higher across a number of different causes of mortality and these differences have been attributed to behavioural differences between men and women. This has led to the suggestion that patriarchy itself may be bad for men's health and lead to their higher mortality. However, there has been no cross national exploration of the relation between different countries' levels of patriarchy and male mortality rates.

\section{What this study adds}

We have shown a substantial and significant association between countries' levels of patriarchy and men's higher mortality. Our data thus suggest that oppression and exploitation harm the oppressors as well as those they oppress. The importance of these findings lies in the implication that men's higher mortality is a preventable social condition, which can potentially be tackled through global social policy measures.

mortality. Our data thus suggest that oppression and exploitation harm the oppressors as well as those they oppress. The same practices that represent men's capacity to oppress women and promote their interest in doing so are also systematically harming men. ${ }^{30}$ Support for this assertion comes from disparate sources. In the USA, men's higher mortality correlates strongly with a number of patriarchy indicators. ${ }^{18}$ In the less patriarchal setting of Israeli kibbutzim, associations have been found between more sex egalitarian social systems and reduced life expectancy differentials between the sexes-these reduced differentials resulting from increases in male life expectancy. ${ }^{31}$ Similar findings have been shown at the level of morbidity and wellbeing. ${ }^{32}$ The importance of these findings lies in the implication that higher male mortality is a preventable social

Table 2 Relation between age standardised female homicide rates and age standardised male mortality rates adjusted for male homicide and GDP ranking

\begin{tabular}{|c|c|c|c|c|c|c|c|c|c|}
\hline \multirow[b]{2}{*}{ Variable } & \multirow{2}{*}{$\begin{array}{l}\text { Unadjusted } \beta \\
\text { coefficient }\end{array}$} & \multirow[b]{2}{*}{ Significance } & \multicolumn{2}{|l|}{$95 \% \mathrm{Cl}$} & \multirow{2}{*}{$\begin{array}{l}\text { Adjusted } \beta \\
\text { coefficient }\end{array}$} & \multirow[b]{2}{*}{$t$} & \multirow[b]{2}{*}{ Significance } & \multicolumn{2}{|l|}{$95 \% \mathrm{Cl}$} \\
\hline & & & Lower & Upper & & & & Lower & Upper \\
\hline Constant & 738.6 & $<0.005$ & 673.4 & 805.8 & 503.543 & 7.41 & $<0.005$ & 366.833 & 640.253 \\
\hline $\begin{array}{l}\text { Female homicide rate } \\
\text { (ln) }\end{array}$ & 202.329 & $<0.005$ & 139.7 & 264.1 & 275.354 & 4.638 & $<0.005$ & 155.918 & 394.791 \\
\hline GDP ranking & & & & & 215.784 & 4.837 & $<0.005$ & 126.041 & 305.527 \\
\hline Male homicide rate $(\ln )$ & & & & & -101.918 & -2.185 & 0.037 & -195.739 & -8.097 \\
\hline
\end{tabular}


condition, which can potentially be tackled through global social policy measures.

In a broader social context, it has often been asserted in human rights and philosophical discourse that oppression also harms the oppressor, through the alienation that results from internalising the "privileges" of oppression. It can readily be envisaged that this will have health relevant psychosocial effects.

The factor used as an indicator of patriarchy, female homicide, is not optimal and other factors could have been used such as political participation, earnings, or reproductive rights. ${ }^{18}$ However, our selection of this factor was in part determined by the availability and quality of cross national data on other indicators. In terms of availability, international sources often only provide total rather than sex specific data. In terms of quality, while data are available on some other factors, such as the percentage of women in politics or the female to male wage ratio, the quality of much of these data is questionable. ${ }^{25}$ For example, the women in politics data exhibit high year on year variability, and the female to male wage ratio data are based only on estimates. ${ }^{25}$ However, it is important to acknowledge that the study is limited by using only one factor as an indicator of patriarchy.

Similarly, it must be noted that patriarchy is by no means an easily definable, uncontested, or easily measurable concept. Different articulations of patriarchy exist within the feminist literature. For example, some commentators, such as Brownmiller, ${ }^{33}$ focus on male power and control over women's sexuality; others, such as Firestone, ${ }^{34}$ highlight the control and power that men have over women's reproductive capacity, and more materialist feminists, such as Delphy ${ }^{35}$ or Williams, ${ }^{36}$ argue that the family is a patriarchal mode of production in which women and men represent opposing classes. Similarly, there are debates about where patriarchal oppression is sited-at the family or individual level (private patriarchy) or at the societal level (public patriarchy). ${ }^{19} 2437$ We have attempted to encapsulate both sites of oppression within our indicator. However, as it is difficult to define patriarchy, it is equally difficult to adequately measure all aspects of it. Furthermore, patriarchy is a contested concept and it has been criticised on the basis that it assumes that oppression on the grounds of sex is experienced equally by all women (and men). Consequently, it is claimed that patriarchy is a somewhat limited concept as it does not take into account the role of other diverse forms of oppression, such as class or race, or indeed reflect the diversity of experienced oppression within sexes (for example, gendered men and gendered women). This has led to some commentators, such as Connell, articulating more multidimensional theories of sex and oppression. Our population level research is unable to engage with this debate, as individual level data are required for a more multidimensional analysis. ${ }^{38} 39$

Further research to identify other appropriate indicators of patriarchy and to explore further the association between patriarchy and poorer health among men is required. Such research should take into account the impact of level of economic development. In addition, a study using data from African nations would permit a more complete comparison. Finally, research is needed at the individual level in addition to the population level. Work is also required to develop interventions aimed at preventing the almost globally endemic patriarchal gender roles resulting from parenting and early socialisation. ${ }^{40}{ }^{41}$ This is an enormous, but in principle achievable task: the rewards will more than justify the efforts.

\footnotetext{
Authors' affiliations

D Stanistreet, A Scott-Samuel, Division of Public Health, University of Liverpool, UK
}

C Bambra, Centre of Health and Public Policy, Wolfson Institute, University of Durham, UK

Funding: none.

Conflicts of interest: none.

\section{REFERENCES}

1 Millet K. Sexual politics. New York: Ballatine, 1970:24-5

2 Chapman J. The feminist approach. In: Marsh D, Stoker G, eds. Theories and methods in political science. London: Macmillan, 1995:98.

3 Bayne-Smith M. Race, gender and health. London: Sage, 1996.

4 Clark J. Sexism, Feminism and medicalism: a decade review of literature on gender and illness. Sociology of Health and Illness 1983;10:521-42.

5 Doyal L. What makes women sick? Gender and the political economy of health. New Brunswick: Ruygers University Press, 1995.

6 Krieger N, Fee E. Man-made medicine and women's health. Intl J Health Serv 1994;24:265-83.

7 Annandale E, Hunt K. Masculinity, femininity and sex: an exploration of their relative contribution to explaining gender differences in health. Sociology of Health and Illness 1990;12:24-46.

8 Courtenay W. Constructions of masculinity and their influence on men's wellbeing: a theory of gender and health. Soc Sci Med 2000;50:1385-401.

9 Kaplan M, Marks G. Appraisal of health risks: the roles of masculinity, femininity, and sex. Sociology of Health and Illness 1995;17:206-21.

10 Lee C, Glynn Owens R. The psychology of men's health. Buckingham: Open University Press, 2002

11 Lorber J. Gender and the social construction of illness. London: Sage, 1997.

12 Sabo D, Frederick Gordon D, eds. Men's health and illness: gender, power and the body. London: Sage, 1995.

13 United Nations. Sex differentials in life expectancy and mortality in developed countries. Popul Bull U N 1998;25:65-106.

14 Waldron I. Recent trends in sex mortality ratios for adults in developed countries. Soc Sci Med 1993;36:451-62.

15 Stillion J. Premature death among males. In: Sabo D, Frederick Gordon D, eds. Men's health and illness: gender, power and the body. London: Sage, 1995:46-67.

16 Waldron I. Contributions of changing gender differences in behaviour and social roles to changing gender differences in mortality. In: Sabo D, Frederick Gordon D, eds. Men's health and illness: gender, power and the body. London: Sage, 1995:22-45.

17 Connell RW. Gender and power: society, the person and sexual politics. Cambridge: Polity, 1987.

18 Kawachi I, Kennedy B, Gupta V, et al. Women's status and the health of women and men: a view from the States. Soc Sci Med 1999:48:21-36.

19 Borchost A, Siim B. Women and the advanced welfare state: a new kind of patriarchal power? In: Showstack-Sassoon A, eds. Women and the state. London: Routledge, 1987.

20 Dahlerup $\mathrm{D}$. Confusing concepts - confusing reality: a theoretical discussion of the patriarchal state. In: Showstack-Sassoon A, ed. Women and the state. London: Routledge, 1987:93-127.

21 Dominelli L. Women across continents. Hemel Hempstead: Harvester Wheatsheaf, 1991

22 Korpi W. Faces of inequality: gender, class and patterns of inequalities in different types of welfare states. Social Politics 2000;7:127-92.

23 Siim B. The gendered Scandinavian welfare states. In: Lewis J, ed. Women and social policies across Europe. Aldershot: Edward Elgar, 1993:25-48.

24 Walby, S. Theorising patriarchy. Cambridge: Blackwell, 1990.

25 United Nations. Statistics and indicators on women and men 2004, http:// unstats.un.org/unsd/demographic/products/indwm/indwm2.htm (accessed 13 Jan 2005).

26 World Health Organisation. Facts sheet no 239: violence against women. Geneva: WHO, 2001

27 Ruxton S. Men, masculinities and poverty in the UK. Oxford: Oxfam, 2002.

28 World Health Organisation. World health statistics annual. Geneva: WHO, 1997.

29 United Nations Development Programme. Human development report Oxford: Oxford University Press, 1997.

30 New C. Oppressed and oppressors? The systematic mistreatment of men. Sociology 2001;35:729-48.

31 Leviatan U, Cohen J. Gender differences in life expectancy among Kibbutz members. Soc Sci Med 1985;2:545-51

32 Anson O, Levenson A, Bonneh DY. Gender and health on the Kibbutz. Sex Roles 1990;22:213-35.

33 Brownmiller S. Against our will: men, women and rape. New York: Simon and Schuster, 1975

34 Firestone S. The dialectic of sex. New York: Bantam, 1970

35 Delphy C. Close to home: a materialist analysis of women's oppression. London: Hutchinson, 1984.

36 Williams F. Social policy: a critical introduction. Cambridge: Polity, 1989.

37 Hernes $\mathrm{H}$. Women and the welfare state: the transition from private to public dependence. In: Showstack-Sassoon A, ed. Women and the state. London: Routledge, 1987:72-92.

38 Connell RW. Masculinities. Cambridge: Polity, 1995.

39 Connell RW. Gender. Cambridge: Polity, 2002.

40 Stewart-Brown S. Emotional wellbeing and its relation to health. BMJ 1998:317:1608-9.

41 Stewart-Brown S. What causes social inequalities: why is this question taboo? Critical Public Health 2000;10:233-42. 


\section{APPENDIX}

Data on age standardised all cause male mortality rates and age standardised female homicide rates

\begin{tabular}{|c|c|c|c|}
\hline Country & $\begin{array}{l}\text { Age standardised male } \\
\text { mortality rate per } 100000 \\
\text { population* }\end{array}$ & $\begin{array}{l}\text { Age standardised female } \\
\text { homicide rate per } 100000 \\
\text { population* }\end{array}$ & $\begin{array}{l}\text { Income ranking based on } \\
\text { GDP per capita† }\end{array}$ \\
\hline Israel & 467.90 & 0.60 & 1.00 \\
\hline Sweden & 521.80 & 0.70 & 1.00 \\
\hline Canada & 549.50 & 1.00 & 1.00 \\
\hline Greece & 555.60 & 0.60 & 2.00 \\
\hline Australia & 564.70 & 1.30 & 1.00 \\
\hline Norway & 583.90 & 0.70 & 1.00 \\
\hline France & 586.30 & 0.70 & 1.00 \\
\hline Italy & 591.70 & 0.50 & 1.00 \\
\hline Spain & 602.80 & 0.50 & 1.00 \\
\hline Netherlands & 605.60 & 0.90 & 1.00 \\
\hline UK & 626.20 & 0.50 & 1.00 \\
\hline Austria & 638.60 & 0.90 & 1.00 \\
\hline Cuba & 640.30 & 3.40 & 2.00 \\
\hline Singapore & 642.80 & 1.10 & 1.00 \\
\hline Luxembourg & 644.20 & 0.50 & 1.00 \\
\hline Germany & 657.70 & 0.80 & 1.00 \\
\hline US & 669.40 & 3.80 & 1.00 \\
\hline Belgium & 670.50 & 1.00 & 1.00 \\
\hline Costa Rica & 671.00 & 1.30 & 2.00 \\
\hline Finland & 680.40 & 1.90 & 1.00 \\
\hline Denmark & 692.90 & 0.80 & 1.00 \\
\hline Chile & 719.70 & 0.70 & 2.00 \\
\hline Ireland & 724.60 & 0.30 & 2.00 \\
\hline Portugal & 751.10 & 1.10 & 1.00 \\
\hline Colombia & 757.50 & 10.70 & 2.00 \\
\hline Slovenia & 787.00 & 1.10 & 2.00 \\
\hline Mexico & 795.90 & 3.40 & 2.00 \\
\hline Venezuela & 798.60 & 2.10 & 2.00 \\
\hline Bahamas & 805.00 & 4.80 & 1.00 \\
\hline Barbados & 807.10 & 3.10 & 2.00 \\
\hline Rep Korea & 811.90 & 1.20 & 2.00 \\
\hline Thailand & 830.50 & 2.30 & 2.00 \\
\hline Albania & 844.30 & 1.50 & 3.00 \\
\hline Croatia & 875.90 & 1.60 & 2.00 \\
\hline Czech & 877.70 & 1.10 & 2.00 \\
\hline Trinidad & 883.30 & 6.40 & 2.00 \\
\hline Brazil & 946.50 & 3.30 & 2.00 \\
\hline Slovakia & 947.50 & 1.20 & 2.00 \\
\hline Poland & 963.80 & 1.30 & 2.00 \\
\hline Tajikistan & 982.10 & 2.50 & 3.00 \\
\hline Afghanistan & 1027.90 & 0.40 & 3.00 \\
\hline Azerbaijan & 1033.30 & 1.90 & 3.00 \\
\hline Romania & 1062.70 & 1.90 & 2.00 \\
\hline Hungary & 1136.10 & 1.80 & 2.00 \\
\hline Lithuania & 1161.90 & 5.70 & 2.00 \\
\hline Estonia & 1297.90 & 4.90 & 2.00 \\
\hline Kyrgyzstan & 1338.80 & 6.10 & 3.00 \\
\hline Rep Moldova & 1396.70 & 6.60 & 2.00 \\
\hline Latvia & 1443.00 & 8.40 & 2.00 \\
\hline Kazakhstan & 1503.80 & 8.30 & 2.00 \\
\hline Russia & 1560.60 & 11.60 & 2.00 \\
\hline
\end{tabular}

